ISSN 1392-3196 / e-ISSN 2335-8947

Zemdirbyste-Agriculture, vol. 103, No. 4 (2016), p. 397-404

DOI 10.13080/z-a.2016.103.051

\title{
Screening of native Trichoderma harzianum isolates for their ability to control Verticillium wilt of strawberry
}

\author{
Seyed Mahyar MIRMAJLESSI ${ }^{1}$, Marika MÄND ${ }^{1}$, Neda NAJDABBASI ${ }^{1}$, \\ Inmaculada LARENA ${ }^{2}$, Evelin LOIT $^{1}$ \\ ${ }^{1}$ Institute of Agricultural and Environmental Sciences, Estonian University of Life Sciences \\ Kreutzwaldi 5, 51014 Tartu, Estonia \\ E-mail: m.mirmajlessi@gmail.com \\ ${ }^{2}$ National Institute for Agricultural Research and Technology (INIA) \\ Ctra. de La Coruna km. 7, 28040 Madrid, Spain
}

\begin{abstract}
In this research, the antagonistic potential of native Trichoderma harzianum isolates toward important strawberry pathogen Verticllium dahliae was studied. For this purpose, fungi were isolated from the rhizosphere and soil from five different strawberry production sites in Estonia over two growing seasons and were investigated under laboratory and greenhouse conditions. T. harzianum colonies were recovered using a selective medium after 12 days and confirmed through species-specific primers. In the laboratory, although all isolates of Trichoderma produced volatile and non-volatile metabolites, seven isolates which had the strongest inhibitory effects on mycelial growth of pathogen were selected for greenhouse assays. In the greenhouse, the disease severity was measured in a split plot treatment design with seven antagonist isolates applied to the two main treatment factors (soil and root), in which all levels of each factor were used in combination with all other factor levels. The result of greenhouse experiments showed that there was no significant difference among T. harzianum treatments but, among selected T. harzianum isolates, TU79 was the most effective isolate for inhibiting the effects of strawberry Verticillium wilt. In the cross-interaction between the antagonist isolates and their treatments, the minimum disease severity was significantly recorded when both soil and roots were treated with TU79 isolate. However, there was no statistically significant difference when this isolate was applied to the soil alone. The results of this study demonstrated that native $T$. harzianum isolates collected from Estonian fields have potential biocontrol ability so that they may be extensively used to control Verticillium wilt in strawberry nurseries.
\end{abstract}

Key words: non-volatile metabolites, Trichoderma harzianum, Verticillium wilt, volatile metabolites.

\section{Introduction}

Strawberry (Fragaria $\times$ ananassa Duch.) is one of the world's most commercially important fruit crops (Suga et al., 2013). According to Food and Agriculture Organization (FAO) statistics (FAOSTAT, 2013), global strawberry production was $4,516,810$ tons in 2012 , and in Estonia, strawberry is grown for fruit and plant production and it is developing into a promising horticultural crop for small growers. Hence, a lot of effort has been made to uphold strawberry production in the different regions of the country. A considerable limiting factor is strawberry diseases that severely influence both fruit and plant production and are frequently challenging to control. Most strawberry cultivars are susceptible to major fungal diseases. Verticillium wilt, caused by soil inhabiting Verticillium dahliae Kleb, is one of the most important diseases worldwide, resulting in great economic losses in many crops like strawberry and can be severe on some cultivars, even at low inoculum densities (Mirmajlessi et al., 2015). The fungus is distinguished from other closely related fungi by producing multicellular and melanized structures known as microsclerotia that persist in the soil, promoting survival between crops (Klosterman et al., 2009). Because of long viability of microsclerotia, the control of the pathogen is difficult even where nonsusceptible hosts have been grown, suggesting that nonhosts may serve as a pathogen reservoir.

Intensive use of fungicides has caused drastic problems of chemical residues in the environment. Due to the change of attitude in the current European policy regarding crop protection, the European Commission has approved a legislative agreement (Directive 2009/128/ EC), which regulates the use of plant protection products and establishing the integrated control and non-chemical means as a fundamental strategy to fight against diseases, pests and weeds. Therefore, the use of synthetic pesticides is being progressively diminished, and it is supplemented by an increased reliance on the use of microorganisms as biocontrol. In plant pathology, biological suppression of plant diseases has been increasingly recognized as a promising alternative way to achieve sustainable agricultural systems as it is safe to use and environmentally friendly, preventing pollution and health hazards resulting from the conventional use of chemicals (Zheng et al., 2011). Biocontrol systems 
frequently use natural living microorganisms known as antagonists that are capable of reducing the effects of undesirable microorganisms. Antagonism implies direct interaction between two microorganisms that share the same ecological niche. Such antagonists can compete with pathogens for nutrients, diminish pathogens by parasitism, inhibit growth of pathogens through antibiosis or even induce systemic resistance in plants (Shishido et al., 2005). Earlier studies demonstrated that the volatile and non-volatile compounds of a variety of fungal microorganisms inhibit the activity of pathogenic fungi. For instance, Padder and Sharma (2011) showed the efficacy of some fungal isolates including Trichoderma viride, T. harzianum, T. hamatum and Gliocladium virens in inhibiting the in vitro and in vivo growth of Colletotrichum lindemuthianum, the causal agent of cowpea anthracnose by using volatile and non-volatile extracts. Basically, the efficacy of biological control depends on the development of the antagonist in the rhizosphere zone and colonizing the plants roots, and so the survival qualities of antagonists can be intensely affected by environmental conditions (Larkin, Fravel, 2002).

Trichoderma spp. have been used for many years as antagonists and have a great contribution to the biological control of many fungal plant pathogens, e.g., Rhizoctonia solani (Naeimi et al., 2010), Botrytis cinerea (Cheng et al., 2012), Verticllium dahliae (Xiaojun et al., 2014) and Phytophthora ramorum (Widmer, 2014). Basically, mycoparasitism, competition for space and nutrients, antibiosis through the production of inhibitory metabolites and induction of the plant's systemic resistance have been described as antagonistic mechanisms of Trichoderma spp. (Harman et al., 2004). Each of these mechanisms may play a key role during antagonism. Among Trichoderma species, T. harzianum Rifai has been applied as an antagonist agent and it behaves efficiently under different environmental conditions to protect crops against diseases. Although some Trichoderma species are among the most investigated fungal biocontrol agents as biofungicide in plant disease management, full-scale application of biological control has not been widespread.

The objectives of the current study were (i) to obtain different Trichoderma harzianum isolates from the rhizosphere of field-grown strawberries as a potential antagonists against Verticillium dahliae; (ii) to assess the possible role of volatile and non-volatile compounds produced by T. harzianum isolates for control of Verticillium wilt of strawberry under greenhouse conditions.

\section{Material and methods}

Verticllium dahliae isolates. During 2014-2015, soil samples were collected from several strawberry fields, located in different production sites in Estonia, that were suspected of being infected with Verticillium wilt (Table 1). $V$. dahliae was isolated from the soil by wet-sieving plating method as previously described by Harris et al. (1993) with some modifications. Briefly, soil samples were air dried for two weeks at room conditions, mixed and ground with a mortar and pestle. Samples were then sifted using a 20-mesh sieve (Tyler equivalent) to eliminate large and unbreakable debris. Twenty g of each sieved soil sample was shaken at $250 \mathrm{rpm}$ and dispersed in distilled water for one hour. Then the soil was wet sieved through 60 and 400 mesh sieves, sequentially, and residue retained in the 400 mesh sieve was suspended in $100 \mathrm{ml}$ distilled water. Aliquots of $1 \mathrm{ml}$ from each suspension were scattered onto 90-mm Petri plates of Czapek's Dox agar supplemented with streptomycin $\left(100 \mathrm{mg} \mathrm{l}^{-1}\right)$ and incubated in the dark at $26^{\circ} \mathrm{C}$. After two weeks' incubation, the plates were carefully washed with distilled water to remove remaining soils. Afterwards, drained plates were scanned for the existence of typical star-shaped colonies of $V$. dahliae using a stereomicroscope Olympus SZX10 (Japan). Hyphal tips grown out from each piece of tissue were picked and transferred to fresh potato dextrose agar (PDA) plates until further use.

Table 1. Detection of Verticillium dahliae in strawberry fields

\begin{tabular}{|c|c|c|}
\hline $\begin{array}{l}\text { Isolate } \\
\text { code }\end{array}$ & $\begin{array}{c}\text { Location } \\
\text { (coordinates) }\end{array}$ & Symptoms in field \\
\hline SV-05 & \multirow{9}{*}{$\begin{array}{l}\text { Vasula } \\
\left(58^{\circ} 47^{\prime} \mathrm{N}, 26^{\circ} 73^{\prime} \mathrm{E}\right)\end{array}$} & plant collapse and death \\
\hline SV-07 & & yellow wilt \\
\hline SV-11 & & wilting, initially older leaves only \\
\hline SV-14 & & poor growth and stunting \\
\hline SV-15 & & poor growth and stunting \\
\hline SV-17 & & yellow wilt \\
\hline SV-19 & & plant collapse and death \\
\hline SV-20 & & yellow wilt \\
\hline SV-21 & & green dry necrosis \\
\hline SR-32 & \multirow{6}{*}{$\begin{array}{l}\text { Rohu } \\
\left(59^{\circ} 09^{\prime} \mathrm{N}, 26^{\circ} 48^{\prime} \mathrm{E}\right)\end{array}$} & yellow wilt \\
\hline SR-36 & & wilting, initially older leaves only \\
\hline SR-38 & & plant collapse and death \\
\hline SR-39 & & no symptoms \\
\hline SR-41 & & yellow wilt \\
\hline SR-43 & & no symptoms \\
\hline SM-46 & \multirow{6}{*}{$\begin{array}{l}\text { Marjamaa } \\
\left(58^{\circ} 90^{\prime} \mathrm{N}, 24^{\circ} 42^{\prime} \mathrm{E}\right)\end{array}$} & plant collapse and death \\
\hline SM-48 & & poor growth and stunting \\
\hline SM-49 & & poor growth and stunting \\
\hline SM-50 & & yellow wilt \\
\hline SM-53 & & green dry necrosis \\
\hline SM-55 & & plant collapse and death \\
\hline SU-63 & \multirow{5}{*}{$\begin{array}{l}\text { Unipiha } \\
\left(58^{\circ} 26^{\prime} \mathrm{N}, 26^{\circ} 58^{\prime} \mathrm{E}\right)\end{array}$} & no symptoms \\
\hline SU-65 & & yellow wilt \\
\hline SU-67 & & yellow wilt \\
\hline SU-68 & & poor growth and stunting \\
\hline SU-69 & & no symptom \\
\hline ST-76 & \multirow{3}{*}{$\begin{array}{l}\text { Utsu } \\
\left(58^{\circ} 40^{\prime} \mathrm{N}, 26^{\circ} 80^{\prime} \mathrm{E}\right)\end{array}$} & no symptoms \\
\hline ST-78 & & no symptoms \\
\hline ST-79 & & yellow wilt \\
\hline
\end{tabular}

Trichoderma harzianum isolates. Soil samples were collected from the surface $(10-20 \mathrm{~cm})$ layer around healthy plant roots and their rhizosphere zone from different sites of strawberry fields, placed in plastic bags and stored at $4^{\circ} \mathrm{C}$ until processing. The samples were air dried (at $27^{\circ} \mathrm{C}$ ), sifted with 20 -mesh sieve to eliminate large debris. One gram of each sample was added to $40 \mathrm{~mL}$ distilled water and shaken by hand for one minute. The suspensions were diluted to $10^{-3}$ and then $0.5 \mathrm{~mL}$ aliquots were removed and spread on plates containing Trichoderma selective medium described previously by Elad et al. (1982). The medium consisted of a basal medium including $1.0 \mathrm{~g} \mathrm{~K}_{2} \mathrm{HPO}_{4}, 0.3 \mathrm{~g} \mathrm{MgSO}_{4}$ $\left(7 \mathrm{H}_{2} \mathrm{O}\right), 1.0 \mathrm{~g} \mathrm{NH}_{4} \mathrm{NO}_{3}, 3 \mathrm{~g}$ glucose, $0.18 \mathrm{~g} \mathrm{KCl}, 20 \mathrm{~g}$ agar and $0.18 \mathrm{~g}$ rose Bengal. Cultures were incubated at $27^{\circ} \mathrm{C}$ under continuous fluorescent light. Monoconidial cultures were identified 12 days after incubation by using the identification key provided by Bissett (1991). To confirm the existence of $T$. harzianum, genomic DNA of each isolate was extracted and amplified by conventional polymerase chain reaction (cPCR) using specific primers THITS-F2 (CGGGTTTTTTATAATCTGAGCC) 
and THITS-R3 (CATTCAGAAGTTGGGTG)

to

T. harzianum (Miyazaki et al., 2009).

Pathogenicity test. All isolates of $V$. dahliae collected from different strawberry fields were subjected to the pathogenicity test on the susceptible strawberry cultivar 'Sonata', using the root dip and soil inoculation methods.

Root dip inoculation. Nine-day-old cultures of $V$. dahliae isolates were washed with sterile distilled water from each plate. The inoculum concentration was adjusted to $10^{6}$ conidia $\mathrm{ml}^{-1}$ by a spectrophotometer. The strawberry seedlings were uprooted, washed under running tap water and submerged in a conidial suspension. After two hours, the inoculated seedlings were planted in $20 \mathrm{~cm}$ pots containing a mixture of perlite, peat moss and vermiculite (1:1:1 by volume) and kept on a greenhouse bench at $24 \pm 1^{\circ} \mathrm{C}$ with 12 hour day length provided by fluorescent light. Then, appearance of wilt symptoms was observed 30 days after inoculation.

Soil inoculation. Isolates of $V$. dahliae were applied after forming microsclerotia on PDA plates. Strawberry seedlings were inoculated with the whole agar piece removed from the plate beneath the roots in pots four weeks after planting. Three replications of four plants for each isolate were designed. The plants were kept under the same conditions as described above. Wilt incidence was observed 30 days after inoculation and its severity was rated on an arbitrary $0-5$ point ranking scale, where $0=$ healthy (no visual symptoms), $1=1 \%$ to $20 \%$ diseased (marginal and interveinal browning of outer leaves), $2=21 \%$ to $40 \%$ diseased, $3=41 \%$ to $60 \%$ diseased, $4=61 \%$ to $80 \%$ diseased and $5=81 \%$ to $100 \%$ diseased (Mirmajlessi et al., 2012). Pathogenicity of each isolate was calculated as follows:

$\sum\left(\frac{\text { Disease index } \times \text { number of inoculated root samples in each index }}{\text { Maximum index } \times \text { total number of inoculated root samples }}\right) \times 100$.

Pathogenicity tests were repeated three times using a randomized complete block design and virulence was measured using disease severity.

In vitro testing of antagonistic effects of T. harzianum isolates on V. dahlia. Inhibition of mycelial growth. T. harzianum isolates were tested in vitro for their antagonistic ability over $V$. dahliae in dual culture. Among all collected $V$. dahliae, one isolate was used as it exhibited the highest level of pathogenicity towards strawberry plants. After colony diameter reached $1.5 \mathrm{~cm}$, a mycelial disc ( $5 \mathrm{~mm}$ in diameter) of each $T$. harzianum isolate and selected $V$. dahliae were placed together $(5$ $\mathrm{cm}$ apart) in a $9 \mathrm{~cm}$ Petri dish containing PDA medium and incubated at $26^{\circ} \mathrm{C}$. Three replications were used per each Trichoderma-Verticillium combination. The experiment was assessed based on the inhibitory effect of the antagonist on radial growth of $V$. dahliae four days after incubation using the following formula:

Growth inhibition $(\%)=(\mathrm{CDC}-\mathrm{CD} / \mathrm{CDC}) \times 100$,

where $\mathrm{CDC}$ is the average diameter of the $V$. dahliae colony as control, $\mathrm{CD}$ - the average diameter of the $V$. dahliae colony in culture medium affected by T. harzianum.

Effects of volatile metabolites. To determine the effects of volatile extracts released by $T$. harzianum isolates on the growth of $V$. dahliae, $5 \mathrm{~mm}$ diameter discs removed from the leading edge of a 10-day-old culture of selected $V$. dahliae were transferred into the centre of PDA plates and incubated at $26^{\circ} \mathrm{C}$ for 7 days prior to the interaction test. Discs from each of the T. harzianum isolates, removed from the leading edge of cultures grown on PDA, were placed on fresh PDA medium before the interaction occurred. The lids of Petri dishes were removed when a plate containing $V$. dahliae was placed over a plate containing T. harzianum and each pair was sealed by adhesive tape. The plates were incubated at $26^{\circ} \mathrm{C}$ for two weeks. The diameter of $V$. dahliae colonies affected by antagonist metabolites was measured and the percentage growth inhibition was then calculated as described above. The control set included cultures of $V$. dahliae paired with uninoculated PDA plates.

Effects of secondary metabolites. To evaluate effects of secondary metabolites (non-volatile) released by the $T$. harzianum isolates on $V$. dahliae, $5 \mathrm{~mm}$ mycelial discs were removed from the leading edge of 10-day-old culture of T. harzianum and transferred to the centre of PDA plates overlaid with sterilized cellophane membranes (Courtauld films, 50- $\mu \mathrm{m}$ thickness). After 72 hours, the cellophane and fungus were removed and a $5 \mathrm{~mm}$ disc of $V$. dahliae was then transferred on the centre of each plate. All plates were incubated at $26^{\circ} \mathrm{C}$ for two weeks and the percentage of growth inhibition was calculated as described above. The plates with cellophane film but without antagonist were employed as controls. The T. harzianum isolates that most highly inhibited $V$. dahliae growth were chosen for in vivo experiments.

In vivo experiments. Plant inoculation. $V$. dahliae inoculum was prepared by growing the fungus on PDA medium at $25^{\circ} \mathrm{C}$. After eight days, colony spores were washed from the plates with sterilized-distilled water and the resulting conidial suspension was adjusted to $10^{5}$ conidia $\mathrm{ml}^{-1}$ using a spectrophotometer. Strawberry seedlings at the trifoliate leaf stage were uprooted, cleaned from soil with running tap water and superficially wounded to ensure the entrance of the pathogen. Seedlings were root-dipped in fungal inoculum for one hour and then transplanted to a sterile soil and kept at $24 \pm 1^{\circ} \mathrm{C}$ in the greenhouse. Control plants were non-inoculated and the inoculum was replaced with distilled water.

Trichoderma harzianum inoculums. For preparation of antagonist inoculum, each T. harzianum isolate was individually prepared on PDA medium at $25^{\circ} \mathrm{C}$ by adding two mycelial plugs of Trichoderma isolates taken from three-day old cultures into flasks containing watersoaked wheat bran which was sterilized $\left(121^{\circ} \mathrm{C}, 15 \mathrm{psi}\right.$, 10 minutes) and cooled before inoculation. Inoculated flasks were then incubated at $26^{\circ} \mathrm{C}$ for two weeks. The number of T. harzianum in each gram of wheat bran was then measured using a hemocytometer (Sigma, United Kingdom). One gram of inoculated wheat bran was then suspended in $12 \mathrm{ml}$ sterile distilled water and the amount of conidia was measured by counting conidia in one $\mathrm{ml}$ of this suspension. T. harzianum inoculum was added to the soil of each pot at $10^{7}$ conidia per $g$ soil. For root treatment, strawberry seedlings were soaked in this inoculum for two hours.

Antagonist ability of Trichoderma harzianum on strawberry Verticillium wilt in the greenhouse. The antagonist effect of T. harzianum isolates for biological control of $V$. dahliae was investigated in a greenhouse. The experiment was performed by using antagonist treatments on root, soil and both root and soil, and consisted of $T$. harzianum isolates with pathogen, pathogen alone and $T$. harzianum without pathogen. Treatments without antagonist and pathogen were considered as control to ensure the health of plants. After approximately two months of inoculation, plants 
were assessed for Verticillium wilt symptoms using the 0-5 point ranking scale described above. The entire experiment was repeated twice in a split plot treatment trial in which each experiment consisted of a randomized complete block design with three replications and four plants per replication. All pots were kept on a greenhouse bench at $24 \pm 1^{\circ} \mathrm{C}$. All statistical analyses were performed by analysis of variance (ANOVA) using statistical software MSTATC, version 1.42. Means were separated by Duncan's multiple range test $(P \leq 0.05)$.

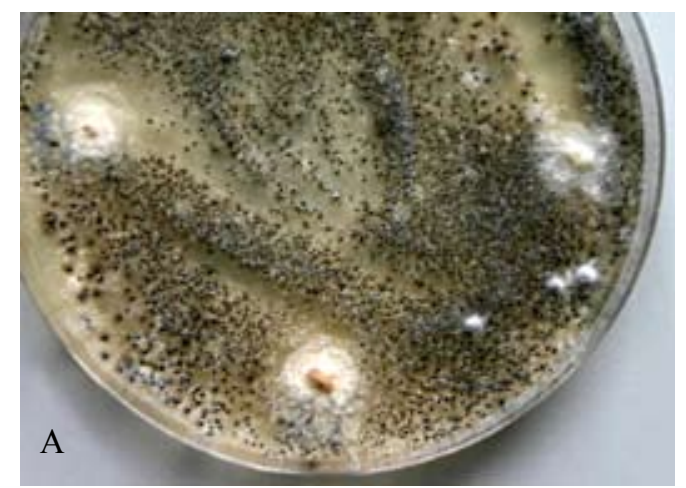

Figure 1. Dark microsclerotia (A) and microscopic mycelium (B)

Isolation of Trichoderma harzianum. Eleven isolates of T. harzianum (TU62, TU63, TU67, TU68, TU70, TU72, TU74, TU75, TU76, TU79 and TU80) were obtained from the rhizosphere of strawberry plants only from the Unipiha area. The species-specific primer (THITS-F2/THITS-R3) was examined using cPCR against genomic DNA from pure culture of $T$. harzianum isolates. PCR products were generated from all DNA extracted using specific primers, demonstrating the existence of amplifiable template. The specific DNA fragments of the expected size were clearly observed by agarose gel electrophoresis for all isolates that confirmed presence of T. harzianum in this study (Fig. 2).

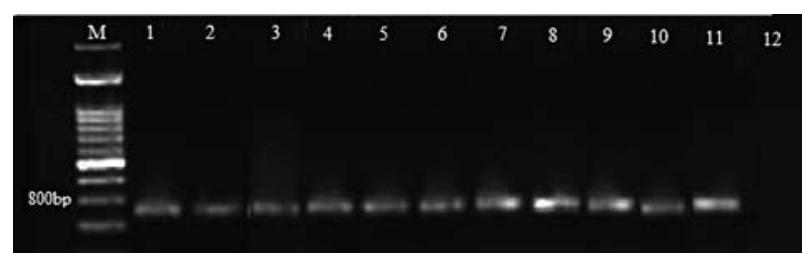

Note. Lane M-100-bp DNA Ladder, lanes 1-11 - specific DNA fragment (approximately $830 \mathrm{bp}$ ) amplified from the genomic DNA of Trichoderma harzianum, lane 12 - distilled water as negative control; agarose gel electrophoresis of PCR products amplified using the primer pair THITS-F2/THITS-R3.

Figure 2. Primer pair specificity

Pathogenicity test of Verticillium dahliae isolates. All isolates of $V$. dahliae were inoculated on strawberry seedlings using root dip and soil inoculation procedures and the percentage of disease severity was recorded. All isolates were found to infect strawberry plants as shown in Table 2.

Combining results of the two inoculation methods indicated that disease severity of isolates varied considerably from $6.8 \%$ to $79.5 \%$ (Table 3 ). The isolates SV-17 and SV-19 collected from Vasula area showed the lowest (6.8\%) and highest (79.5\%) disease severity,

\section{Results}

Isolation of Verticillium dahlia. In this study, 29 isolates of $V$. dahliae were obtained from soil of strawberry fields from different areas of Estonia (Table 1). Identification of $V$. dahliae was based on morphological structures such as production of dark microsclerotia with hyaline and septate mycelium along with ovoid and single-celled conidia on PDA (Fig. 1).

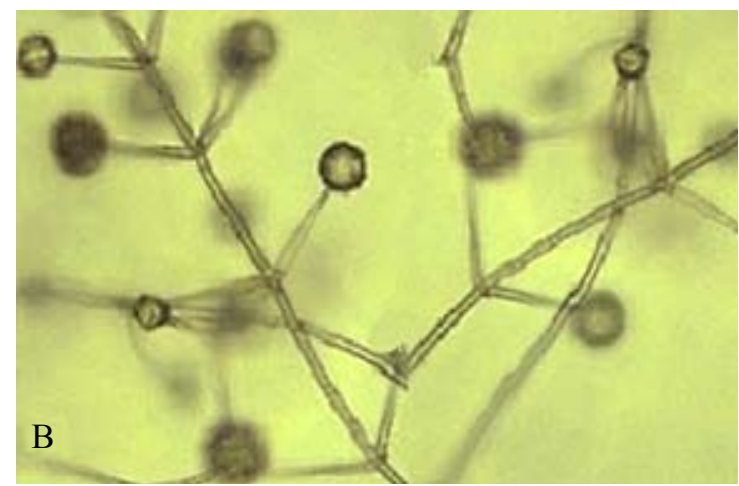

Table 2. Pathogenic variability of Verticillium dahliae isolates on strawberry plants (cv. 'Sonata')

\begin{tabular}{|c|c|c|}
\hline \multirow{2}{*}{$\begin{array}{l}\text { Isolate } \\
\text { code }\end{array}$} & \multicolumn{2}{|c|}{ Disease severity $\%$} \\
\hline & root dip inoculation & soil inoculation \\
\hline SV-05 & $31 \mathrm{bc}$ & $33.7 \mathrm{bcd}$ \\
\hline SV-07 & $56.6 \mathrm{ab}$ & $44.2 \mathrm{abcd}$ \\
\hline SV-11 & $56.6 \mathrm{ab}$ & $68.1 \mathrm{ab}$ \\
\hline SV-14 & $56.6 \mathrm{ab}$ & $44.2 \mathrm{abcd}$ \\
\hline SV-15 & $56.6 \mathrm{ab}$ & 44.2 abcd \\
\hline SV-17 & $11 \mathrm{~d}$ & $4.3 \mathrm{ef}$ \\
\hline SV-19 & $76.6 \mathrm{a}$ & $86.3 \mathrm{a}$ \\
\hline $\mathrm{SV}-20$ & $56.6 \mathrm{ab}$ & $20 \mathrm{de}$ \\
\hline SV-21 & $56.6 \mathrm{ab}$ & $44.2 \mathrm{abcd}$ \\
\hline SR-32 & $56.6 \mathrm{ab}$ & $54.3 \mathrm{abc}$ \\
\hline SR-36 & $31 \mathrm{bc}$ & $20 \mathrm{de}$ \\
\hline SR-38 & $56.6 \mathrm{ab}$ & $33.7 \mathrm{bcd}$ \\
\hline SR-39 & $56.6 \mathrm{ab}$ & $68.1 \mathrm{ab}$ \\
\hline SR-41 & $31.0 \mathrm{bc}$ & $54.3 \mathrm{abc}$ \\
\hline SR-43 & $56.6 \mathrm{ab}$ & $26.6 \mathrm{~cd}$ \\
\hline SM-46 & $31 \mathrm{bc}$ & $54.3 \mathrm{abc}$ \\
\hline SM-48 & $56.6 \mathrm{ab}$ & $54.3 \mathrm{abc}$ \\
\hline SM-49 & $56.6 \mathrm{ab}$ & $26.6 \mathrm{~cd}$ \\
\hline SM-50 & $31 \mathrm{bc}$ & $44.2 \mathrm{abcd}$ \\
\hline SM-53 & $56.6 \mathrm{ab}$ & $54.3 \mathrm{abc}$ \\
\hline SM-55 & $31 \mathrm{bc}$ & $44.2 \mathrm{abcd}$ \\
\hline SU-63 & $31 \mathrm{bc}$ & $20 \mathrm{de}$ \\
\hline SU-65 & $56.6 \mathrm{ab}$ & $28.1 \mathrm{~cd}$ \\
\hline SU-67 & $31 \mathrm{bc}$ & $44.2 \mathrm{abcd}$ \\
\hline SU-68 & $31 \mathrm{bc}$ & 8.1 ef \\
\hline SU-69 & $31 \mathrm{bc}$ & $28.1 \mathrm{~cd}$ \\
\hline ST-76 & $31 \mathrm{bc}$ & $8.1 \mathrm{ef}$ \\
\hline ST-78 & $31 \mathrm{bc}$ & 8.1 ef \\
\hline ST-79 & $31 \mathrm{bc}$ & $8.1 \mathrm{ef}$ \\
\hline Control & $0 \mathrm{e}$ & $0 \mathrm{~g}$ \\
\hline
\end{tabular}

Note. Means in the same column followed by different letters differ from each other significantly at $P \leq 0.05$ (Duncan's multiple range test); control - without $V$. dahliae.

respectively. In summary, the disease severity was $<20 \%$ in six isolates, between $20 \%$ and $80 \%$ in 22 isolates and only one isolate revealed a disease severity of around $80 \%$.

Moreover, a combined disease severity resulting from the use of two inoculation methods on strawberry 
Table 3. Combined pathogenic variability of Verticillium dahliae isolates on strawberry plants (cv. 'Sonata') inoculated by root dip and soil inoculation procedures

\begin{tabular}{cccc}
\hline Isolates & $\begin{array}{c}\text { Disease } \\
\text { severity } \\
\%\end{array}$ & Isolates & $\begin{array}{c}\text { Disease } \\
\text { severity } \\
\%\end{array}$ \\
\hline SV-19 & $79.5 \mathrm{a}$ & SV-20 & $32.5 \mathrm{de}$ \\
SV-11 & $58.4 \mathrm{ab}$ & SV-05 & $32.4 \mathrm{de}$ \\
SR-39 & $58.2 \mathrm{ab}$ & SM-55 & $32.3 \mathrm{de}$ \\
SM-53 & $55.3 \mathrm{abc}$ & SR-43 & $32 \mathrm{de}$ \\
SR-32 & $52.5 \mathrm{abcd}$ & SM-50 & $32.1 \mathrm{de}$ \\
SV-21 & 52 abcd & SU-67 & $31.4 \mathrm{de}$ \\
SM-48 & 51.1 abcd & SU-69 & $25.3 \mathrm{def}$ \\
SV-15 & 47.9 abcd & SU-63 & $23.5 \mathrm{def}$ \\
SV-07 & $43.6 \mathrm{bcd}$ & SR-36 & $17 \mathrm{ef}$ \\
SV-14 & $39.1 \mathrm{cde}$ & ST-78 & $16.2 \mathrm{ef}$ \\
SR-38 & $38.8 \mathrm{cde}$ & ST-76 & $16 \mathrm{ef}$ \\
SM-49 & $38.6 \mathrm{cde}$ & SU-68 & $13.9 \mathrm{efg}$ \\
SM-46 & $38.4 \mathrm{cde}$ & ST-79 & $11.2 \mathrm{fg}$ \\
SR-41 & $37.3 \mathrm{cde}$ & SV-17 & $6.8 \mathrm{~g}$ \\
SU-65 & $35.8 \mathrm{cde}$ & control & $0 \mathrm{~h}$ \\
\hline
\end{tabular}

Note. Means in the columns followed by different letters differ from each other significantly at $P \leq 0.05$ (Duncan's multiple range test); control - without $V$. dahliae.

seedlings showed that the root dip inoculation method presented higher disease severity $(44.2 \%)$ than the soil inoculation method (Table 4). As the most pathogenic isolate, SV-19 was chosen for further investigation.
Table 4. Combined disease severity of two inoculation procedures

\begin{tabular}{lc}
\hline \multicolumn{1}{c}{ Inoculation method } & Disease severity \% \\
\hline Root dip & $44.2 \mathrm{a}$ \\
Soil & $37.1 \mathrm{~b}$ \\
\hline
\end{tabular}

Note. Means in the same column followed by different letters differ from each other significantly at $P \leq 0.05$ (Duncan's multiple range test).

Antagonistic effects of T. harzianum isolates on V. dahlia. Dual culture. In this assay, 11 isolates of $T$. harzianum were tested against $V$. dahlia isolate SV-19 to evaluate mycelial growth inhibition. In dual culture, most Trichoderma isolates grew very fast and showed significant inhibition ability over $V$. dahliae, covering the whole $V$. dahliae colony after four days (data not shown). In two cases (TU62 and TU76), however, an inhibition zone was observed at the contact area of the growing colonies without overgrowth. The percentage of $V$. dahliae colony growth inhibition by all Trichoderma isolates is shown in Table 5.

Volatile metabolites. Volatile metabolites deriving from different $T$. harzianum isolates exhibited a wide range of inhibitory effect on $V$. dahliae, varying from $15.8 \%$ to $88.3 \%$, with isolates TU76 and TU79 showing minimum and maximum effect on the pathogen, respectively (Table 5).

Table 5. Evaluation of dual culture, volatile and non-volatile metabolites tests on mycelial growth inhibition of Verticillium dahliae SV-19

\begin{tabular}{ccccc}
\hline \multirow{2}{*}{$\begin{array}{c}\text { Trichoderma harzianum } \\
\text { isolates }\end{array}$} & \multicolumn{3}{c}{ Mycelial inhibition $\%$} & Average \\
\cline { 2 - 4 } & volatile metabolites & non-volatile metabolites & dual culture & $31.6 \mathrm{~cd}$ \\
TU62 & $24.1 \mathrm{cde}$ & $40.6 \mathrm{ab}$ & $30.1 \mathrm{~cd}$ & $59.7 \mathrm{abc}$ \\
TU63 & $83.1 \mathrm{ab}$ & $35.1 \mathrm{abc}$ & $62.8 \mathrm{bcd}$ & $47.8 \mathrm{abcd}$ \\
TU67 & $52.9 \mathrm{bcd}$ & $28.1 \mathrm{bcd}$ & $75.5 \mathrm{bc}$ & $59.9 \mathrm{abc}$ \\
TU68 & $67.5 \mathrm{bc}$ & $36.6 \mathrm{abc}$ & $61.2 \mathrm{bcd}$ & $41.9 \mathrm{bcd}$ \\
TU70 & $53.3 \mathrm{bcd}$ & $11.2 \mathrm{de}$ & $88.1 \mathrm{ab}$ & $62.9 \mathrm{ab}$ \\
TU72 & $79.8 \mathrm{abc}$ & $20.7 \mathrm{~cd}$ & $85.9 \mathrm{abc}$ & $63.3 \mathrm{ab}$ \\
TU74 & $81.7 \mathrm{ab}$ & $22.2 \mathrm{~cd}$ & $93.1 \mathrm{a}$ & $59.6 \mathrm{abc}$ \\
TU75 & $55.2 \mathrm{bcd}$ & $30.4 \mathrm{abcd}$ & $17.9 \mathrm{de}$ & $28.1 \mathrm{cde}$ \\
TU76 & $15.8 \mathrm{de}$ & $50.5 \mathrm{a}$ & $92.1 \mathrm{a}$ & $66.2 \mathrm{a}$ \\
TU79 & $88.3 \mathrm{a}$ & $18.2 \mathrm{cde}$ & $85.6 \mathrm{abc}$ & $65.7 \mathrm{a}$ \\
TU80 & $80.3 \mathrm{abc}$ & $31.1 \mathrm{abcd}$ & $0 \mathrm{f}$ & $0 \mathrm{f}$ \\
Control & $0 \mathrm{f}$ & $0 \mathrm{f}$ & $\mathrm{abc}$
\end{tabular}

Note. Means in the same column followed by different letters differ from each other significantly at $P \leq 0.05$ (Duncan's multiple range test).

Secondary metabolites. Evaluation of the inhibitory effect of non-volatile metabolites of $T$. harzianum isolates over $V$. dahliae indicated a wide range of mycelial growth inhibition which varied from $11.2 \%$ to $50.5 \%$ (Table 5 ). Generally, based on the results of dual culture, volatile and non-volatile metabolites, seven isolates (TU63, TU68, TU72, TU74, TU75, TU79 and TU80) which showed mycelial inhibition of more than $50 \%$ were chosen for the greenhouse assays.

Antagonistic ability of T. harzianum isolates on strawberry $V$. wilt in the greenhouse. The seven selected isolates of T. harzianum that achieved suitable biocontrol efficacy in in vitro experiments were further evaluated for their antagonistic effects on strawberry Verticillium wilt in greenhouse experiments. As shown in Table 6, treatments affected by different $T$. harzianum isolates resulted in a mean disease severity of $\approx 38 \%$, locating in one statistical group. However, the lowest mean disease severity was related to the soil treatment $(38.4 \%)$. On the other hand, different Trichoderma isolates decreased
Table 6. The effects of different treatments and isolates of Trichoderma harzianum on disease severity of Verticillium wilt in the greenhouse

\begin{tabular}{lc}
\hline \multicolumn{1}{c}{ Treatments } & $\begin{array}{c}\text { Mean disease severity } \\
\%\end{array}$ \\
\hline Root & $38.7 \mathrm{a}$ \\
Soil & $38.4 \mathrm{a}$ \\
Root and soil & $38.5 \mathrm{a}$ \\
\hline V. dahliae* & $75.6 \mathrm{a}$ \\
TU63 + P & $55.8 \mathrm{~b}$ \\
TU68 + P & $56.2 \mathrm{~b}$ \\
TU72 + P & $43.2 \mathrm{bc}$ \\
TU74 + P & $42.5 \mathrm{bc}$ \\
TU75 + P & $55.8 \mathrm{~b}$ \\
TU79 + P & $26.8 \mathrm{~cd}$ \\
TU80 + P & $37.5 \mathrm{bcd}$ \\
Without pathogen & $0 \mathrm{e}$ \\
\hline
\end{tabular}

Note. ${ }^{*}$ - fungal inoculum as positive control, $\mathrm{P}-V$. dahliae isolate SV-19 as pathogen; means in the same column followed by different letters differ from each other significantly at $P \leq 0.05$ (Duncan's multiple range test). 
disease severity in comparison with the control (no Trichoderma inoculation), but the effects of six of the Trichoderma isolates were statistically indistinguishable $(P<0.05)$. Only isolate TU79 showed a significantly reduced disease severity $(\approx 27 \%)$ by its treatment on root or soil.

The cross-interaction between the antagonist isolates and the type of treatment (root, soil and both root and soil) showed a varied range of disease severity from $14.2 \%$ to $75.6 \%$. The maximum disease severity, indistinguishable from the positive control, was found when the root was treated with isolate TU75. Also, the minimum disease severity was observed when inoculate TU79 was applied either to the soil or to both soil and root (Table 7).

Table 7. Interaction between all Trichoderma harzianum isolates and their treatments regarding disease severity of Verticillium wilt in the greenhouse

\begin{tabular}{|c|c|c|}
\hline Fungal isolates & $\begin{array}{l}\text { T. harzianum } \\
\text { treatments }\end{array}$ & $\begin{array}{c}\text { Mean disease } \\
\text { severity } \%\end{array}$ \\
\hline V. dahliae* & - & $75.6 \mathrm{a}$ \\
\hline TU75 + P & root & $75.6 \mathrm{a}$ \\
\hline TU63 + P & root & $55.3 \mathrm{~b}$ \\
\hline TU72 + P & root & $55.3 \mathrm{~b}$ \\
\hline TU68 + P & soil & $55.3 \mathrm{~b}$ \\
\hline TU68 + P & root, soil & $55.3 \mathrm{~b}$ \\
\hline $\mathrm{TU} 75+\mathrm{P}$ & root, soil & $55.3 \mathrm{~b}$ \\
\hline TU63 + P & root, soil & $51.4 \mathrm{bc}$ \\
\hline TU63 + P & soil & $51.4 \mathrm{bc}$ \\
\hline TU68 + P & root & $51.4 \mathrm{bc}$ \\
\hline TU74 + P & soil & $46.3 \mathrm{bcd}$ \\
\hline $\mathrm{TU} 72+\mathrm{P}$ & soil & $46.3 \mathrm{bcd}$ \\
\hline TU72 + P & root, soil & $46.3 \mathrm{bcd}$ \\
\hline TU75 + P & soil & $46.3 \mathrm{bcd}$ \\
\hline TU80 + P & root & $31.5 \mathrm{~cd}$ \\
\hline TU74 + P & root & 28.1 cde \\
\hline $\mathrm{TU} 74+\mathrm{P}$ & root, soil & 28.1 cde \\
\hline TU80 + P & root, soil & $23.3 \mathrm{de}$ \\
\hline TU79 + P & root & $23.3 \mathrm{de}$ \\
\hline TU80 + P & soil & $23.3 \mathrm{de}$ \\
\hline TU79 + P & soil & $14.2 \mathrm{ef}$ \\
\hline TU79 + P & root, soil & $14.2 \mathrm{ef}$ \\
\hline Without pathogen & - & $0 \mathrm{~g}$ \\
\hline
\end{tabular}

Note. ${ }^{*}$ - fungal inoculum as positive control, $\mathrm{P}-V$. dahliae isolate SV-19 as pathogen; means in the same column followed by different letters differ from each other significantly at $P \leq 0.05$ (Duncan's multiple range test).

\section{Discussion}

The use of microorganisms to control plant diseases is an exciting part of applied biology. Endogenous agents including Trichoderma spp. have been considered as a favourable resource for biocontrol of soil-borne pathogens. Since they mostly live in the rhizosphere they can affect the competitive ability of target pathogens like $V$. dahliae. Indeed, the efficacy of Trichoderma spp. as biocontrol agents against phypathogens has been demonstrated in previous studies (Naeimi et al., 2010; Cheng et al., 2012; Widmer, 2014). The present investigation examined multiple criteria to assess the antagonistic activity of several strains of $T$. harzianum against $V$. dahliae, the causal agent of Verticillium wilt of strawberry.

In this study, 29 isolates of $V$. dahliae were collected from various strawberry growing areas in Estonia. The isolates were similar in morphological characteristics but differed in disease severity. The results of the pathogenicity tests showed that $V$. dahliae isolate SV-19 was the most pathogenic, leading to the highest disease severity $(79.51 \%)$, while SV-17 showed the lowest severity $(6.8 \%)$ when seedlings were inoculated by root dipping or soil inoculation methods. Both isolates originated from the same (Vasula) area but generated different wilt symptoms on strawberry plants, reflecting genetic diversity in the $V$. dahliae population. Significant genetic diversity among $V$. dahliae isolates is a common phenomenon that has been reported by Berbegal et al. (2010) who showed a degree of host specificity and different virulence from certain hosts. Also, our results indicated that root inoculation using spore suspension induced greater disease severity than infections initiated by microsclerotia in the soil. However, both inoculation methods were efficacious on plants when analyzed separately. Gordon et al. (2005) illustrated that root dip inoculation method was more consistent over time than soil inoculation method on different strawberry genotypes. As in root dip inoculation the root system is directly subjected to the pathogen propagules, systemic infections are more rapidly predictable than soil inoculations. So, infection will not occur until growing roots encounter microsclerotia in the soil, which may be affected by annual temperatures. However, development of disease may vary between plants inoculated by different methods (Xiaojun et al., 2014).

In the in vitro test, all $T$. harzianum isolates obtained from healthy strawberry rhizospheres successfully inhibited radial growth of the $V$. dahliae (SV-19) by growing faster than the pathogen on PDA in comparison with untreated controls. Competition for space and nutrients could be one of the most general mechanisms applied by biocontrol agent to inhibit mycelial growth of the pathogen. In a similar study, the antagonistic activity of Trichoderma species against Fusarium oxysporum f. sp. pisi has been proved using competition as an effective mechanism where Trichoderma and Fusarium showed varying degree of inhibition on each other, indicating competitive ability of Trichoderma isolates (Sharma, 2011). However, in our study, an inhibition zone through lysis and deformation of $V$. dahliae mycelium was observed at the contact area of the growing colonies without overgrowth only by two isolates of $T$. harzianum (TU62 and TU76), demonstrating the attendance of diffusible inhibitory substances. Besides, production of extracellular enzymes such as chitinase, cellulase and $\beta$-glucanase is another biocontrol mechanism that apply by Trichoderma towards fungal pathogens, which degrade the fungal cell walls (Hassan, 2014). There was no correlation between antagonist capability to produce antifungal antibiosis and growth percentage of $V$. dahliae. Overall, growth inhibition occurred by either production of clear zone between the two colonies or by direct overgrowth on the pathogen in dual cultures. Indeed, the production of fungal metabolites as an indirect mechanism could not be the primary biocontrol mechanism and it might be through inhibition, competition or direct killing of the pathogen mycelium. These direct and indirect mechanisms may have effect on the biocontrol process that depends on the Trichoderma strain, the pathogen and the environmental conditions such as $\mathrm{pH}$, nutrient availability and temperature (Benítez et al., 2004).

In addition, antifungal activity of T. harzianum isolates by production of volatile and non-volatile 
metabolites was also tested in our study. Previous investigations showed that antimicrobial metabolites of Trichoderma spp. are able to inhibit growth of a wide range of plant pathogens such as Staphylococcus aureus, Bipolaris sorokiniana, Bacillus subtilis, Streptococcus faecalis, Clavibacter michiganensis, Rhizoctonia solani, Botrytis cinerea, Curvularia lunata, Colletotrichum lagenarium, C. gloeosporioides, $C$. falcatum and C. acutatum (Xiao-Yan et al., 2006; Porras et al., 2009). It has also been found that there is a large variety of antifungal compounds such as harzianopyridone, harzianolide, azaphilone, diterpenes, peptaibols, butenolides, furanones, pyrones and pyridones produced by $T$. harzianum which play an important role in controlling phytopathogens (Vinale et al., 2006; Siddiquee et al., 2012). In this study, it was observed that volatile or nonvolatile metabolites of $T$. harzianum isolates produced were effective in inhibiting the mycelial growth of tested $V$. dahliae in the culture medium which is in agreement with the general definition of antibiosis as the mechanism mediated by metabolites.

This study also demonstrated that Verticillium wilt of strawberry is controlled efficiently by treating the strawberry soil or root with spore suspensions of $T$. harzianum under greenhouse conditions, whereas severity of disease was significantly reduced in comparison with control plants. In a similar study, intensity of Verticillium disease was reduced when roots of susceptible strawberry seedlings were soaked with $T$. harzianum and $T$. viride isolates, and the treatment was even more effective than the standard fungicide Topsin M (Meszka, Bielenin, 2009). Many studies regarding the efficacy of Trichoderma spp. in reducing disease severity of Verticillium wilt on different hosts have been published, indicating that Trichoderma can be a dominant bio-agent in management strategies. However, decreased severity of Verticillium wilt was found when plants had been treated with other antagonists (Naraghi et al., 2010; Zheng et al., 2011).

\section{Conclusion}

The present study showed the capability of volatile and non-volatile metabolites of Trichoderma harzianum, isolated from field-grown strawberries in the Unipiha area, Estonia in reducing the mycelial growth of Verticillium dahliae. Both volatile and nonvolatile metabolites could be also involved in controlling Verticillium wilt under greenhouse conditions. The outcomes may have practical applications in fields naturally infested by $V$. dahliae with the aim of protecting biological resources as well as confining the use of chemical compounds. Field experiments, efficient formulation and studies on the mechanism of interactions between biocontrol agent, pathogen and plant should be the main goals of future research.

\section{Acknowledgements}

This work was supported by EUPHRESCO (European Phytosanitary Research Coordination) Phytosanitary ERA-Net project SPAT (Strawberry Pathogens Assessment and Testing), European Union through the European Regional Development Fund (contract No. 10.1-9/14/471) and institutional research funding (IUT36-2) of the Estonian Ministry of Education and Estonian Science Foundation (Grant No. 9450). The authors specially thank Prof. Peter Harley (National
Center for Atmospheric Research, Colorado, USA) for critical reading of the manuscript and giving valuable comments. Also, we are very grateful to farmers for their support in the fields.

Received 04052016

Accepted 05092016

\section{References}

Benítez T., Rincón A. M., Limón M. C., Codón A. C. 2004. Biocontrol mechanisms of Trichoderma strains. International Microbiology, 7 (4): 249-260

Berbegal M., Ortega A., Jiménez-Gasco M. M., OlivaresGarcía C., Jiménez-Díaz R. M., Armengol J. 2010. Genetic diversity and host range of Verticillium dahliae isolates from artichoke and other vegetable crops in Spain. Plant Disease 94: 396-404 http://dx.doi.org/10.1094/PDIS-94-4-0396

Bissett J. 1991. A revision of the genus Trichoderma. II Infrageneric classification. Canadian Journal of Botany, 69: 2357-2372 http://dx.doi.org/10.1139/b91-297

Cheng C. H., Yang C. A., Peng K. C. 2012. Antagonism of Trichoderma harzianum ETS 323 on Botrytis cinerea mycelium in culture conditions. Phytopathology. 102 (11): 1054-1063 http://dx.doi.org/10.1094/PHYTO-11-11-0315

Elad Y., Chet I., Henis Y. 1982. Degradation of plant pathogenic fungi by Trichoderma harzianum. Canadian Journal of Microbiology, 28: 719-725 http://dx.doi.org/10.1139/m82-110

Directive 2009/128/EC of the European Parliament and of the Council of 21 October 2009 establishing a framework for Community action to achieve the sustainable use of pesticides. Official Journal of European Union, 309: 71-85

FAOSTAT. 2013. World strawberry production http://faostat.fao. org/site/567/DesktopDefault.aspx?PageID=567\#ancor

Gordon T. R., Shaw D. V., Larson K. D. 2005. Comparative response of strawberries to conidial root-dip inoculations and infection by soilborne microsclerotia of Verticillium dahliae Kleb. HortScience, 40 (5): 1398-1400

Harman G. E., Howell C. R., Viterbo A., Chet I., Lorito M. 2004. Trichoderma species opportunistic, avirulent plant svmbionts. Nature Reviews Microbiology, 2: 43-56 http://dx.doi.org/10.1038/nrmicro797

Harris D. C., Yang J. R., Ridout M. S. 1993. The detection and estimation of Verticillium dahliae in naturally infested soil. Plant Pathology. 42 (2): 238-250 http://dx.doi.org/10.1111/j.1365-3059.1993.tb01496.x

Hassan M. M. 2014. Influence of protoplast fusion between two Trichoderma spp. on extracellular enzymes production and antagonistic activity. Biotechnology and Biotechnological Equipment, 28 (6): 1014-1023 http://dx.doi.org/10.1080/13102818.2014.978206

Klosterman S. J., Atallah L. K., Vallad G. E., Subbarao K. V. 2009. Diversity, pathogenicity, and management of Verticillium species. Annual Review of Phytopathology. 47: 39-62 http://dx.doi.org/10.1146/annurev-phyto-080508-081748

Larkin R. P., Fravel D. R. 2002. Effects of varying environmental conditions on biological control of Fusarium wilt of tomato by nonpathogenic Fusarium spp. Phytopathology, 92 (11): $1160-1166$ http://dx.doi.org/10.1094/PHYTO.2002.92.11.1160

Meszka B., Bielenin A. 2009. Bioproducts in control of strawberry Verticillium wilt. Phytopathology, 52: 21-27

Mirmajlessi S. M., Safaie N., Ahari H. M., Mansouripour S. M., Mahmoudy S. B. 2012. Genetic diversity among crown and root rot isolates of Rhizoctonia solani isolated from cucurbits using PCR based techniques. African Journal of Agricultural Research, 7 (4): 583-590

Mirmajlessi S. M., Destefanis M., Gottsberger R. A., Mänd M., Loit E. 2015. PCR-based specific techniques used for detecting the most important pathogens on strawberry: a svstematic review. Svstematic Review. 4: 9 http://dx.doi.org/10.1186/2046-4053-4-9

Miyazaki K., Tsuchiya Y., Okuda T. 2009. Specific PCR assays for the detection of Trichoderma harzianum causing green mold disease during mushroom cultivation. Mycoscience, 50: 94-99 http://dx.doi.org/10.1007/S10267-008-0460-2 
Naeimi S., Okhovvat S. M., Javan-Nikkhah M., Vagvolgyi C., Khosravi V., Kredics L. 2010. Biological control of Rhizoctonia solani AG1-1A, the causal agent of rice sheath blight with Trichoderma strains. Phytopathologia Mediterranea, 49: 287-300

Naraghi L., Heydari A., Rezaee S., Razavi M., Afshari-Azad H. 2010. Biological control of Verticillium wilt of greenhouse cucumber by Talaromyces flavus. Phytopathologia Mediterranea, 49: 321-329

Padder B. A., Sharma P. N. 2011. In vitro and in vivo antagonism of biocontrol agents against Colletotrichum lindemuthianum causing bean anthracnose. Archives of Phytopathology and Plant Protection. 44 (10): 961-969 http://dx.doi.org/10.1080/03235400903460619

Porras M., Barrau C., Romero F. 2009. Biological control of Anthraconse with Trichoderma in strawberry fields. Acta Horticulturae. 842: 351-354 http://dx.doi.org/10.17660/ActaHortic.2009.842.66

Sharma P. 2011. Complexity of Trichoderma-Fusarium interaction and manifestation of biological control. Australian Journal of Crop Science, 5 (8): 1027-1038

Shishido M., Miwa Ch., Usami T., Amemiya Y., Johnson K. B. 2005. Biological control efficiency of Fusarium wilt of tomato by nonpathogenic Fusarium oxysporum FoB2 in different environments. Phytopathology. 95 (9): 1072-1080 http://dx.doi.org/10.1094/PHYTO-95-1072

Siddiquee S., Cheong B. E., Taslima K., Kausar H., Hasan M. M. 2012. Separation and identification of volatile compounds from liquid cultures of Trichoderma harzianum by GCMS using three different capillary columns. Journal of Chromatographic Science. 50: 358-367

http://dx.doi.org/10.1093/chromsci/bms012
Suga H., Hirayama Y., Suzuki T., Kageyama K., Hyakumachi M. 2013. Development of PCR primers to identify Fusarium oxysnorum f. sn. fragariae. Plant Disease, 97 (5); 619-625 http://dx.doi.org/10.1094/PDIS-07-12-0663-RE

Vinale F., Marra R., Scala F., Ghisalberti E. L., Lorito M., Sivasithamparam K. 2006. Major secondary metabolites produced by two commercial Trichoderma strains active against different phytopathogens. Letters in Applied Microbiology, 43: 143-148 http://dx.doi.org/10.1111/j.1472-765X.2006.01939.x

Widmer T. L. 2014. Screening Trichoderma species for biological control activity against Phytophthora ramorum in soil. Biological Control, 79: 43-48 http://dx.doi.org/10.1016/j.biocontrol.2014.08.003

Xiaojun Ch., Wongkaew S., Jie Y., Xuehui Y., Haiyong H., Shiping W., Qigqun T., Lishuang W., Athinuwat D., Buensanteai N. 2014. In vitro inhibition of pathogenic Verticillium dahliae, causal agent of potato wilt disease in China by Trichoderma isolates. African Journal of Biotechnology, 13 (33): 3402-3412 http://dx.doi.org/10.5897/AJB2013.12195

Xiao-Yan S., Qing-Tao S., Shu-Tao X., Xiu-Lan C., Cai-Yun S., Yu-Zhong Z. 2006. Broad-spectrum antimicrobial activity and high stability of Trichokonins from Trichoderma koningii SMF2 against plant pathogens. FEMS Microbiologv Letters. 260 (1): 119-125 http://dx.doi.org/10.1111/j.1574-6968.2006.00316.x

Zheng Y., Xue Q. Y., Xu L. L., Xu Q., Lu S., Gu, C., Guo J. H. 2011. A screening strategy of fungal biocontrol agents towards Verticillium wilt of cotton. Biological Control, 56: $209-216$

http://dx.doi.org/10.1016/j.biocontrol.2010.11.010

ISSN 1392-3196 / e-ISSN 2335-8947

Zemdirbyste-Agriculture, vol. 103, No. 4 (2016), p. 397-404

DOI $10.13080 / \mathrm{z}-\mathrm{a} .2016 .103 .051$

\title{
Trichoderma harzianum vietinių izoliatų tinkamumas kontroliuoti braškių verticiliozę
}

\author{
S. M. Mirmajlessi ${ }^{1}$, M. Mänd ${ }^{1}$, N. Najdabbasi ${ }^{1}$, I. Larena ${ }^{2}$, E. Loit ${ }^{1}$ \\ ${ }^{1}$ Estijos gyvybės mokslų universiteto Žemès ūkio ir aplinkos mokslų institutas \\ ${ }^{2}$ Ispanijos žemès ūkio tyrimų ir technologijos institutas
}

\section{Santrauka}

Tirtas Trichoderma harzianum vietinių izoliatų antagonizmas braškių patogenui Verticillium dahliae. Tuo tikslu Estijoje penkiose braškiu auginimo vietose du vegetacijos laikotarpius grybai buvo išskirti iš rizosferos bei dirvožemio ir ištirti laboratorijoje bei lauko sąlygomis. T. harzianum kolonijos buvo išskirtos naudojant selektyvinę terpę po 12 dienų ir identifikuotos naudojant rūšiai būdingus pradmenis. Visi Trichoderma izoliatai gamino lakius ir nelakius metabolitus. Tyrimui šiltnamyje buvo pasirinkti septyni izoliatai, kurie pasižymèjo stipriausiu patogeną slopinančiu poveikiu. Šiltnamyje ligos pažeidimas matuotas skaidytų laukelių variantų metodu, naudojant septynis izoliatus dviem pagrindiniams variantų veiksniams (dirvožemiui ir šaknims). Šiltnamio tyrimo duomenys parodè, kad slopinant braškių verticiliozę nebuvo reikšmingo skirtumo tarp T. harzianum izoliatų, bet tarp pasirinktų $T$. harzianum izoliatų efektyviausias buvo TU79. Esant kryžminei sąveikai tarp antagonistinių izoliatų ir jų variantų minimalus ligos pažeidimas buvo esminis, kai dirvožemis ir šaknys buvo paveikti TU79 izoliatu. Tačiau esminis skirtumas nebuvo nustatytas, kai šis izoliatas buvo naudojamas vien tik dirvožemiui. Tyrimo rezultatai parodè, kad vietiniai $T$. harzianum izoliatai, surinkti Estijos laukuose, pasižymi antagonistiniu poveikiu $V$. dahliae ir todèl gali būti plačiai naudojami verticiliozès kontrolei braškių augynuose.

Reikšminiai žodžiai: lakūs metabolitai, nelakūs metabolitai, Trichoderma harzianum, Verticillium dahliae.

Please use the following format when citing the article:

Mirmajlessi S. M., Mänd M., Najdabbasi N., Larena I., Loit E. Screening of native Trichoderma harzianum isolates for their ability to control Verticillium wilt of strawberry. Zemdirbyste-Agriculture, 103 (4): 397-404 DOI 10.13080/z-a.2016.103.051 